\title{
Hvordan står det til med legeerklæringene?
}

\author{
Leger kurses i å samtale med pasientene, men deres skriftlige ferdigheter får liten oppmerksomhet. \\ Bak hver av de ca. 300000 uføretrygdede i Norge finnes minst én og ofte flere legeerklæringer. Kvaliteten \\ på disse tekstene vet vi lite om.
}

Leger er sentrale premissleverandører i uføresaker. Dette er slått fast i en offentlig rapport der fastlegenes erklæringer tillegges avgjørende betydning for NAVs vedtak (1). Men hva skriver legene i sine erklæringer? I en SINTEF-rapport fra 2006 gir et panel av rådgivende leger i NAV og spesialister følgende omtrentlige karakteristikk av legeerklæringer som er skrevet av allmennleger: «Noen er veldig gode, noen er akseptable, noen er verdiløse og noen er skandaløse» (2).

Gjennom skriving av journalnotater og sakkyndighetserklæringer produserer leger en omfattende mengde sakprosa som ikke er tilgjengelig for offentligheten, men som har store konsekvenser for individ og samfunn. Vår erfaring er at mange leger betrakter legeerklæringer og legeattester som ekstra kontorarbeid som stjeler tid fra deres kliniske virksomhet. Dette reflekterer antakelig den lave statusen legererklæringer har hos leger.

Selv ved svært mangelfulle legeerklæringer er det vår erfaring at NAV ikke returnerer disse til legene for å innhente mer informasjon. I stedet velger de å sende saken til en spesialist - ikke for videre medisinsk utredning, men for å få en ny og spesialistforfattet legeerklæring. En av oss (GA) arbeider som rådgivende overlege i NAV. Erfaringen derfra er at det sjelden er nødvendig med spesialisterklæring der fastlegen har skrevet en god legeerklæring.

\section{Språklig kompetanse}

Mens det å skrive god skjønnlitteratur krever spesiell begavelse, er det å «kunne skrive innenfor sitt fag» noe de fleste kan lære seg (3). Det dreier seg imidlertid ikke bare om å beherske en bestemt type tekst (med for eksempel medisinske uttrykk), men en hel sjanger. For dette formålet kan man definere sjanger som et mønster for hvordan kommunikasjonen skal være mellom partene i forskjellige kontekster, dvs. i en bestemt situasjon innen en gitt kultur (4). Legeerklæringens kulturkontekst er de lovbaserte kravene til utforming, men den enkelte erklæring formes også av møtet mellom pasienten og legen, altså situasjonskonteksten. Forskrifter, som ofte kan være detaljerte, retningslinjer og veiledere for attester/ legeerklæringer $(5,6)$ kan begrense attestskriverens frihet. For øvrig har de ulike skjemaene flere spesifiserte krav.

Leger vet at det ligger et skjønn bak vurderingen i de fleste uføresaker. Dette står i motsetning til et uførebegrep som «noe fast, kanskje noe absolutt og noe kvantifiserbart» som NAV forventer at legen må kunne uttale seg om (7). Å formidle pasientopplysninger som er relevante, objektive, fullstendige og etterprøvbare (5), stiller desto større krav til sjangerkompetanse. Hvordan utforme legeerklæringen på en måte som gir høy kvalitet og legitimitet (5)? Ved større avvik fra sjangeren kan legen skape utydelighet og gi mottakeren (NAV) utvidet subjektivt tolkingsrom, med mulighet for å gjøre feil vedtak eller trekke det ut i tid. NAV, på sin side, ber legen gjøre vurderinger som ligger utenfor medisinens anliggende - for eksempel om behandlingen fører til bedring av arbeidsevnen.

\section{«Gjennom språket skaper vi virkelighets- bilder»}

Det direkte målet med medisinsk behandling er imidlertid sjelden å bedre arbeidsevnen - målet for behandling er å bedre helse og hjelpe individet til å håndtere sykdom. Det er i dette skjæringspunktet legen skriver erklæringer, og det er i denne konteksten teksten blir til.

\section{Språkets metafunksjoner}

Hva gjør denne utfordringen med språket i legeerklæringen? For å kunne svare på dette, kan vi undersøke sentrale språklige metafunksjoner (8):

- Hvordan forstår og presenterer legen pasientens virkelighetsverden? Hvordan presenterer og begrunner legen sammenhengen mellom sykdom, funksjonsevne og arbeidsevne? Hva slags informasjon velges ut og hva blir valgt bort?

- Hvilket relasjonelt «samspill» med mottakeren, som for eksempel er saksbehandler, legger teksten opp til? I hvilken grad formidler legen sine egne holdninger, sine forbehold og sin usikkerhet?

- Hvilke grammatiske og retoriske virkemidler benytter legen i sin tekst for å skape en overordnet sammenheng? Er tekstens mønster hovedsakelig refererende, argumenterende eller utredende?
Den australske lingvisten Michael Halliday sier at språket representerer verden gjennom språket skaper vi virkelighetsbilder. I likhet med sakprosaforfattere i sin alminnelighet har legen mulighet til å presentere virkelighetsbilder ved å vektlegge bestemte temaer, forutsetninger og perspektiver som kan påvirke hvordan mottakeren forstår teksten - uten at lovkravene brytes. Legene mener ikke at de «skriver usant $i$ attestene, det er hvordan fakta vektlegges det dreier seg om», skriver Guldbrandsen og medarbeidere i en artikkel i Tidsskriftet (9). «Friheten» forfatterne av uføreerklæringer har til å utforme sine tekster er stor og kan neppe oppheves av en forskrift. Derfor kan ikke hele problemet med tekstene i legeerklæringer om uførhet løses ved å lage enda flere regler for utforming. Etter vår mening bør arbeidet også bestå i å hjelpe legene med å bli bedre til å skrive disse tekstene.

Aktørenes roller i en uføresak er innbyrdes asymmetriske, også sett i et tekstperspektiv. Den som skriver og som besitter medisinsk kompetanse (legen) har saklig sett ingen interesse av sakens utfall. Den det skrives om (pasienten), kommer ikke direkte til orde. Og det forventes at den som leser og tolker teksten (saksbehandleren), ikke har noen direkte kjennskap til pasienten. Vi kan spørre hvordan legens tekst kan kommunisere godt og effektivt i en slik sammenheng. En detaljert og systematisk analyse av legeerklæringer vil kunne belyse dette.

\section{Guri Aarseth \\ guri.aarseth@legepost.no \\ Anne H. Kveim Lie \\ Bård Natvig}

Guri Aarseth (f. 1951) er spesialist i allmennmedisin. Hun har en engelsk mastergrad i Medical Humanities fra London og har studert litteratur, kommunikasjon og retorikk ved Universitetet i Oslo. Hun er fastlege og rådgivende lege i NAV Vestfold.

Forfatter har fylt ut ICMJE-skjemaet og oppgir ingen interessekonflikter.

Anne H. Kveim Lie (f. 1969) er dr.med., førsteamanuensis i medisinsk historie ved Universitetet i Oslo og medisinsk redaktør i Tidsskriftet. Forfatter har fylt ut ICMJE-skjemaet og oppgir ingen interessekonflikter. 
Bård Natvig (f. 1955) er spesialist i samfunnsmedisin, dr.med. og førsteamanuensis i allmennmedisin ved Universitetet i Oslo. Han er dessuten rådgivende lege $\mathrm{i}$ forsikringsmedisin. Forfatter har fylt ut ICMJE-skjemaet og oppgir ingen interessekonflikter.

\section{Litteratur}

1. Norges offentlige utredninger. En ny arbeids- og velferdsforvaltning. Om samordning av Aetats, trygdeetatens og sosialetatens oppgaver. NOU 2004: 13.
2. Steihaug S, Hem K. Evaluering av forsøk med bruk av legespesialister og rådgivende leger i uføresaker. SINTEF-rapport nr. 257/2006. Oslo: SINTEF 2006.

3. Hellspong L, Ledin P. Vägar genom texten. Handbok i brukstextanalys. Lund: Studentlitteratur, 1997: 28.

4. Maagerø E. Språket som mening. Oslo: Universitetsforlaget, 2005.

5. Forskrift om krav til helsepersonells attester, erklæringer o.l. FOR 2008-12-18 nr 1486 www.lovdata.no/for/sf/ho/xo-20081218-1486.htm (17.9.2012).

6. Mæland G. Veileder i trygdemedisin. 6. utg. Oslo: Gyldendal Akademisk, 2010

7. Solli HM. Rettferdighet og objektivitet i trygde- medisinske uførhetsvurderinger. En etisk og vitenskapsfilosofisk analyse av tre uførhetsmodeller $i$ et historisk perspektiv. Oslo: Det norske medicinske Selskab, 2007

8. Halliday MAK, Matthiessen C. An introduction to functional grammar. 3. utg. London: Hodder Education, 2004.

9. Gulbrandsen P, Aasland OG, Førde R. Legeattester for å hjelpe pasienten. Tidsskr Nor Lægeforen 2004: 124: 192-4.

Mottatt 10.8. 2012, første revisjon innsendt 11.9 2012, godkjent 17.9. 2012. Medisinsk redaktør Petter Gjersvik.

\title{
Eksponering for støy ved ortopediske prosedyrer
}

\author{
Eksponering for støy er en hovedårsak til permanent hørseltap. Støymålinger tyder på betydelig støy- \\ eksponering for de tilstedeværende under ortopediske prosedyrer.
}

Ansatte som utfører ortopediske prosedyrer der det benyttes elektriske og luftdrevne ortopediske verktøy, er i perioder trolig eksponert for høye støynivåer. Støynivået ved slike prosedyrer i Norge har ikke tidligere vært undersøkt med personbårne måleinstrumenter. Vi har nå forsøkt å kvantifisere dette (1).

Målingene ble utført på to ortopedistuer ved Oslo universitetssykehus, Ullevål, samt ved operasjonsavdelingen ved Oslo legevakt i 2010-11. Støyende prosedyrer

\section{«Ved planlegging av nye operasjonsstuer må støydemping inngå i design og utforming»}

omfattet særlig protesekirurgi og enkelte kneoperasjoner. Støyen ble målt med et støydosimeter der mikrofonen ble festet på kragen til den kirurgen som var hovedoperatør under prosedyren. Dataloggeren ble lagt i lommen til kirurgen.

Støynivået ble målt ved 13 ortopediske prosedyrer - operasjoner der det ble satt inn kne- og hofteproteser, meniskoperasjoner, ryggoperasjoner og skulderoperasjoner. Gjennomsnittlig operasjonstid ved innsetting av kne- og hofteproteser var henholdsvis 147 minutter og 130 minutter.

Gjennomsnittsstøyen ved kneproteseinn- setting varierte i området $83-85 \mathrm{dBA}$, for hofteproteseoperasjoner var den i området 80-86 dBA. Høyeste impulsstøy ble målt ved hofteproteseoperasjon (135 dBC), avstiving av kne (129 dBC), skulderproteseoperasjon (128 dBC) og kneproteseoperasjon (126 dBC). Alle måleverdiene var lavere enn grenseverdiene (Threshold Limit Values, TLV) til American Conference of Governmental Industrial Hygienists (ACGIH).

Målingene tyder på at det er et forholdsvis høyt støynivå ved ortopediske prosedyrer. Ved en ortopedisk avdeling vil det være relevant å vurdere mulige tekniske tiltak som avskjerming av støy, eventuelt innbygging av støykilden, utskifting av enkelte verktøy som støyer mye og godt vedlikehold av utstyr. Dessuten bør man stille krav og sette betingelser til støynivået ved anskaffelse av nytt utstyr. Andre tiltak kan være å vurdere arbeidsmetoder som gir mindre støyeksponering og støyreduserende kommunikasjonsutstyr. Ved planlegging av nye operasjonsstuer må støydemping inngå i design og utforming.

\section{Elin Watts \\ Pål Brenno \\ Per Søstrand \\ Kristine Lillelund \\ Tor Erik Danielsen \\ toedan@ous-hf.no}

Elin Watts (f. 1978) er bedriftslege ved ExxonMobil, Stavanger.

Forfatter har fylt ut ICMJE-skjemaet og oppgir ingen interessekonflikter.
Pål Brenno (f. 1967) er bedriftslege ved Arbeidsmiljøavdelingen, Oslo universitetssykehus, Rikshospitalet

Forfatter har fylt ut ICMJE-skjemaet og oppgir ingen interessekonflikter.

Per Søstrand (f. 1950) er yrkeshygieniker ved Seksjon for miljø- og yrkesmedisin, Oslo universitetssykehus, Ullevål.

Forfatter har fylt ut ICMJE-skjemaet og oppgir ingen interessekonflikter.

Kristine Lillelund (f. 1976) er yrkeshygieniker ved Arbeidsmiljøavdelingen, Oslo universitetssykehus, Rikshospitalet.

Forfatter har fylt ut ICMJE-skjemaet og oppgir ingen interessekonflikter.

Tor Erik Danielsen (f. 1960) er seksjonsleder, overlege ved Seksjon for miljø- og yrkesmedisin, Oslo universitetssykehus, Ullevål.

Forfatter har fylt ut ICMJE-skjemaet og oppgir ingen interessekonflikter.

Litteratur

1. Watts E, Brenno P, Søstrand P et al. Eksponering for støy ved ortopediske prosedyrer i Oslo universitetssykehus. Ramazzini 2012; 19: 11-2. https://legeforeningen.no/PageFiles/95074/ Ramazzini\%202.2012\%20LR.pdf (16.9.2012).

Mottatt 6.8. 2012, første revisjon innsendt 14.8. 2012, godkjent 20.9. 2012. Medisinsk redaktør Erlend Hem. 